EWA OLSZOWY*_KATOWICE

\title{
DARY AUTORSKIE DLA BIBLIOTEKI ŚLĄSKIEGO SEMINARIUM DUCHOWNEGO W LATACH 1928-1939 (PRZYCZYNEK DO BADAŃ NAD ZAWARTOŚCIĄ PRZEDWOJENNEGO KSIĘGOZBIORU)
}

Wśród współczesnych księgozbiorów kościelnych szczególne miejsce zajmują biblioteki wyższych seminariów duchownych. Ich historia sięga XVI w., kiedy dekretem Soboru Trydenckiego (1545-1563) Cum adolescentium aetas z 1563 r. biskupi zostali zobowiązani do powołania w swoich diecezjach seminariów kształcących kandydatów do kapłaństwa. W wyniku realizacji dekretu, jeszcze w tym samym stuleciu, na ziemiach polskich erygowano m.in. seminarium wrocławskie, warmińskie, włocławskie, poznańskie ${ }^{1}$. Po kilkuset latach funkcjonowania tej formy szkolnictwa teologicznego wciąż niezastąpioną rolę w formacji kapłańskiej odgrywają księgozbiory seminaryjne, zapewniając nie tylko warsztat naukowy, ale i kształtując umysłowość, rozwój duchowy oraz zainteresowania czytelnicze duchowieństwa. Wiele z nich może poszczycić się bogatymi zasobami, na które, oprócz systematycznie gromadzonych książek, składają się niejednokrotnie zbiory bibliotek klasztornych, kapitulnych czy diecezjalnych przejęte w wyniku rozmaitych wydarzeń dziejowych oraz, co wydaje się być cechą charakterystyczną, liczne prywatne kolekcje kapłanów. Wszystko to sprawia, że każda $\mathrm{z}$ bibliotek seminaryjnych zasługuje na wnikliwe prace badawcze prowadzące zarówno do odtworzenia dziejów, jak i scharakteryzowania zawartości zbiorów bibliotecznych.

W artykule zaprezentowano fragment wyników badań prowadzonych nad przedwojennym zasobem Biblioteki Śląskiego Seminarium Duchownego utworzonego w Krakowie w latach dwudziestych ubiegłego stulecia. Przyjmuje się, że

* Ewa Olszowy - mgr historii, asystent biblioteczny w Bibliotece Teologicznej Uniwersytetu Śląskiego w Katowicach.

${ }^{1}$ Zob. J. Gręźlikowski, Początki realizacji dekretu „Cum adolescentium aetas” Soboru Trydenckiego w Polsce, w: Ars boni et aequi. Księga pamiątkowa dedykowana księdzu profesorowi Remigiuszowi Sobańskiemu z okazji osiemdziesiątej rocznicy urodzin, red. J. Wroceński, H. Pietrzak, Warszawa 2010, s. 263-289. 
biblioteka seminaryjna wraz z czytelnią rozpoczęła funkcjonowanie w momencie wprowadzenia się do wybudowanego dla seminarium budynku w dniu 4 października 1927 r. ${ }^{2}$. W 1980 r. Wyższe Śląskie Seminarium Duchowne, w tym i bibliotekę, przeniesiono do Katowic, a w 2000 r. powołano Bibliotekę Teologiczną dla nowo utworzonego Wydziału Teologicznego, która przejęła „w użyczeniu” księgozbiór seminaryjny.

Seminaryjne zasoby biblioteczne nie doczekały się jak dotąd szczegółowego omówienia. Historię biblioteki przybliżają publikacje autorstwa ks. Tadeusza Czakańskiego ${ }^{3}$ oraz rozprawa Bogumiły Warząchowskiej ${ }^{4}$. Część zbiorów została przedstawiona przez Weronikę Pawłowicz w pracy poświęconej prywatnym kolekcjom śląskich kapłanów ${ }^{5}$, natomiast zagadnienia komputeryzacji biblioteki i katalogowania opracowała Jolanta Szulc ${ }^{6}$. Nadal jednak odczuwa się brak materiałów opisujących księgozbiór w sposób kompleksowy, poczynając od sposobu jego gromadzenia, źródeł wpływu, polityki doboru, stopnia narastania, a kończąc na analizie rzeczowej.

Niezastąpione źródło do przeprowadzenia badań nad zbiorami bibliotecznymi stanowi inwentarz biblioteki ${ }^{7}$. Zachował się pierwszy, liczący 478 kart, Inwentarz Bibljoteki Ślaskiego Seminarium Duchownego w Krakowie. Odnotowano w nim nabytki za lata 1928-1957, w sumie 5450 dzieł. Zbiory opisywane były w rubrykach: nr bieżący, nazwisko i imię autora, tytuł, liczba tomów, dział, miejsce wydania, rok wydania, wydawca lub skład główny, objętość, rodzaj oprawy, data nabycia, w jaki sposób nabyto, data zniszczenia, nr wskazujący miejsce na półce, format, uwagi.

Analiza inwentarza pokazuje, że od początku istnienia biblioteki zbiory w dużym stopniu były zasilane poprzez liczne dary, w tym testamentalne, jak również zakupy prywatnych księgozbiorów księży. Wszystkie darowizny warte są odrębnego i pogłębionego opracowania, część z pewnością stanie się tematem obszerniejszych rozpraw ${ }^{8}$.

${ }^{2}$ T. Czakański, Historia Biblioteki Wyższego Śląskiego Seminarium Duchownego, w: Wyższe Śląskie Seminarium Duchowne 1924-2004, red. J. Kupny, Katowice 2004, s. 283.

${ }^{3}$ Tenże, Historia Biblioteki, s. 283-292; tenże, Biblioteka Wyższego Ślaskiego Seminarium Duchownego, „Gość Niedzielny”, 50 (1997) s. 17.

${ }^{4}$ B. Warząchowska, Książka, prasa i biblioteka $w$ działalności Kościoła katolickiego w województwie śląskim (1922-1939), Katowice 2012, s. 232-241.

${ }^{5}$ W. Pawłowicz, Księgozbiory polskiego duchowieństwa katolickiego na Górnym Śląsku w XIX i XX wieku (do 1939 r.), Katowice 2009.

${ }^{6}$ J. Szulc, Opracowanie rzeczowe zbiorów w Bibliotece Wyższego Śląskiego Seminarium Duchownego w Katowicach, „Fides-Biuletyn Bibliotek Kościelnych”, 1/2 (1997) s. 216-220; taż, Automatyzacja Biblioteki Wyższego Ślaskiego Seminarium Duchownego w Katowicach, „Fides-Biuletyn Bibliotek Kościelnych”, 1 (1998) s. 83-91; taż, Komputeryzacja Biblioteki Wyższego Śląskiego Seminarium Duchownego w Katowicach, „Bibliotekarz”, 7/8 (2000) s. 33-35.

${ }^{7}$ Zob. B. Pytlos, Inwentarz jako źródto badań księgozbiorów bibliotecznych (na przykładzie księgozbioru Biblioteki Wydziału Teologicznego Uniwersytetu Śląskiego w Katowicach), w: Piśmiennictwo pragmatyczne w Polsce do końca XVIII wieku na tle powszechnym, pod red. J. Gancewskiego i A. Wałkówskiego, Olsztyn 2006, s. 278-285.

${ }^{8}$ Przykładem może być liczący ponad 850 dzieł księgozbiór bpa Teofila Bromboszcza. 
Przedmiotem niniejszych rozważań są tzw. dary autorskie, czyli publikacje przekazane do zbiorów biblioteki przez samych autorów, a oznaczone w inwentarzu jako „dar autora”. Za ramy chronologiczne przyjęto lata 1928-1939, czyli niewiele ponad pierwszą dekadę kształtowania się księgozbioru, w czasie której zarejestrowano 3873 pozycje. Ogółem odnotowano 50 egzemplarzy przekazanych przez 30 osób, w tym 27 kapłanów, przede wszystkim archidiecezji krakowskiej i diecezji katowickiej, jak również 3 osoby świeckie. Chociaż dary autorskie stanowią niewielki liczebnie fragment przedwojennego zasobu i na ich podstawie nie można przedstawić jego pełnej charakterystyki, to mogą jednak posłużyć za punkt wyjścia do dalszych badań nad darami, dzięki którym znacznie powiększały się zbiory biblioteki. Być może informacja o przekazanych publikacjach przyczyni się ponadto do wzbogacenia wiedzy na temat samych darczyńców i uzupełnienia ich biogramów.

Najwięcej publikacji swojego autorstwa przekazali do zbiorów tworzącej się biblioteki seminaryjnej przedstawiciele archidiecezji krakowskiej co zapewne wynikało z usytuowania na jej terenie śląskiego seminarium. Dominowali profesorowie Wydziału Teologicznego Uniwersytetu Jagiellońskiego, na wykłady których uczęszczali śląscy alumni, a którzy na trwałe zapisali się w dziejach polskiej teologii: ks. Jan Fijałek, bp Michał Godlewski, ks. Tadeusz Kruszyński, ks. Jan Krzemieniecki, ks. Konstanty Michalski, ks. Jan Piwowarczyk, ks. Jan Salamucha, ks. Maciej Sieniatycki, ks. Władysław Wicher.

Pierwszym egzemplarzem autorskim odnotowanym w inwentarzu jest podręcznik akademicki Zarys dogmatyki katolickiej. T. 1: O Bogu jedynym i trójosobowym (Kraków 1928)9 ks. Macieja Sieniatyckiego (1869-1949), profesora katedry teologii dogmatycznej, czterokrotnego dziekana Wydziału Teologicznego. Było to ważne dzieło, które wraz z innym podręcznikiem - Apologetyka czyli dogmatyka fundamentalna - zawiera „solidną doktrynę katolicką, gruntownie przez autora rozważoną oraz umiejętnie podaną, na wzór najlepszych tego rodzaju dzieł zagranicznych" ${ }^{\prime 10}$. W tym samym 1928 r. do zbiorów wpłynęły kolejne dary wykładowców uczelni. Początki cenzury prewencyjnej w Kościele RzymskoKatolickim i w Polsce (Kraków 1928) przekazał najwybitniejszy ówczesny historyk Kościoła w Polsce, ks. Jan Fijałek (1864-1936) ${ }^{11}$ opatrując dedykacją: „Bibljotece Seminarjum Duchownego Śląskiego w Krakowie autor 16.V.1928” oraz wpisem informującym, że praca stanowi nadbitkę z Księgi ku czci Aleksandra Brücknera. Biskup pomocniczy diecezji łucko-żytomierskiej Michał Godlewski (1872-1956), historyk Kościoła katolickiego w Cesarstwie Rosyjskim, kierownik katedry historii Kościoła powszechnego, ofiarował publikację Cesarz Aleksander I jako mistyk. Szkic historyczny z niewydanych źródet (Kraków 1923). Warto przypomnieć, że na długo przed objęciem katedry na uniwersytecie bp Godlewski był

${ }^{9} \mathrm{~W}$ latach późniejszych do zbiorów biblioteki wpłynęły kolejne 3 tomy podręcznika, które zostały dopisane w inwentarzu pod tym samym nr 974, nie odnotowano jednak żadnej informacji o sposobie ich przekazania.

${ }^{10}$ E. Florkowski, Śp. Ks. Maciej Sieniatycki, „Polonia Sacra”, 2 (1949) s. 199.

${ }^{11}$ O twórczości ks. Fijałka zob. A. Vetulani, Ks. Jan Fijałek historyk Kościoła Polskiego, „Polonia Sacra", 1 (1997) s. 293-317. 
profesorem oraz bibliotekarzem petersburskiej Akademii Duchownej ${ }^{12}$. Z kolei ks. Konstanty Michalski CM (1879-1947), światowej sławy profesor filozofii chrześcijańskiej i ówczesny dziekan Wydziału Teologicznego, podarował opublikowany w 1924 r. na łamach „Przeglądu Współczesnego” artykuł Centra ruchu neoscholastycznego. Ks. Michalski w misjonarskim Instytucie Teologicznym pełnił funkcję bibliotekarza, a jako rektor uniwersytetu zajął się m.in. rozbudową Biblioteki Jagiellońskiej ${ }^{13}$.

Z „Przeglądu Teologicznego” pochodzi publikacja Dalmatyka i tunicella obok kapy w stroju pontyfikalnym (Lwów 1928) przekazana przez ks. Tadeusza Kruszyńskiego (1884-1959), wykładowcę sztuki kościelnej i liturgiki. W 1933 r. zbiory biblioteki wzbogaciły się o następne dzieło duchownego: Właściwości stylowe polskich monet i pieczęci od czasu Renesansu (Kraków 1933). Był to jedyny dar autorski zarejestrowany w inwentarzu w tym roku. W 1934 r. do księgozbioru włączony został kolejny artykuł - Jerzy Pencz z Norymbergii jako twórca malowidet tryptyku w Kaplicy Zygmuntowskiej (Warszawa 1934). Ofiarowywane prace ks. Kruszyński podpisywał - na odwrocie karty tytułowej Właściwości stylowe... znajduje się dedykacja: „Bibjotece Śląskiego Seminarium Duchownego składa swą pracę ks. Kruszyński” wraz z dopisaną u góry datą: „Kraków 10.I.1933”, a na Jerzy Pencz... wpis: „Kraków 21.IV.1934 Czytelni Seminarium Śląskiego składa ks. Kruszyński”.

Również w 1928 r. w księgozbiorze biblioteki znalazło swoje miejsce dzieło Idea odpowiedzialności w życiu społecznym. Studjum socjologiczne (Katowice 1925) autorstwa ks. Franciszka Mirka (1893-1970), socjologa związanego od 1926 r. z Poznańską Szkołą Socjologiczną Floriana Znanieckiego, współredaktora krakowskiego „Dzwonu Niedzielnego” i poznańskiego „Postępu”. Z kolei w 1932 r. ks. Jan Piwowarczyk (1889-1959), wykładowca nauk społecznych na Wydziale Teologicznym UJ podarował Kryzys społeczno-gospodarczy w świetle katolickich zasad (Kraków 1932). Dysertacja, na podstawie której ks. Piwowarczyk uzyskał stopień doktora teologii, nosi dedykację: „Dla Bibljoteki Śląskiego Seminarium duch. w Krakowie autor. Kraków, 23.IV.1932”. Ks. Piwowarczyk był pierwszym redaktorem naczelnym „Tygodnika Powszechnego”, w 1951 r. odsunięto go od prowadzenia wykładów, oskarżono o działalność antypaństwową, a rok później zmuszono do opuszczenia Krakowa ${ }^{14}$. Należy dodać, że wspomniane publikacje ks. Mirka i ks. Piwowarczyka zostały w 1960 r. skonfiskowane przez władze PRL w ramach przeprowadzonej w dniach 22-24 sierpnia na terenie całego kraju kontroli bibliotek seminariów duchownych, diecezjalnych i zakonnych oraz innych instytucji kościelnych. Obydwie prace dotyczyły kwestii społecznych, a książki poruszające m.in. tego rodzaju zagadnienia budziły zastrzeżenia władz. „Zabezpieczone" w wyniku akcji publikacje zostały zwrócone Kościołowi w 1997 r. Książki skonfiskowane ze zbiorów Biblioteki Śląskiego Seminarium Duchownego zostały przekazane Bibliotece Teologicznej w 2004 r. ${ }^{15}$.

${ }^{12}$ Złota księga Papieskiej Akademii Teologicznej, pod red. S. Piecha, Kraków 2000, s. 398.

${ }^{13}$ Tamże, s. 434, 437.

${ }^{14}$ Tamże, s. 487-488.

${ }^{15}$ O kontroli biblioteki zob.: Czakański, Libri Martyres. Gdy ksią̇ka była wrogiem, w: Wyższe Śląskie Seminarium, s. 293-298; Warząchowska, Dzieje książek skonfiskowanych w roku 1960 w Bi- 
W 1934 r. księgozbiór wzbogacił się o dzieło wybitnego polskiego kanonisty ks. Jana Krzemienieckiego (1887-1956) - Bernardinus Gallellus de Jadra vicarius et officialis generalis Cracoviensis 1509-1517 (Cracoviae 1934). Praca z historii prawa kanonicznego opatrzona została dedykacją: „Bibljotece Seminarjum Śląskiego autor"'.

W latach 1936-1937 trzy prace złożył w darze ks. Jan Salamucha (1903-1944), profesor filozofii chrześcijańskiej, jeden ze współzałożycieli szkoły filozoficznej Koło Krakowskie. Artykuły ogłoszone na łamach „Przeglądu Filozoficznego": Logika zdań u Wilhelma Ockhama (Warszawa 1935), Współczesna neoscholastyka włoska (Warszawa 1936) i Pojawienie się zagadnień antynomialnych na gruncie logiki średniowiecznej (Warszawa 1937) stanowiły dowód naukowych zainteresowań autora historią filozofii, w szczególności logiką ${ }^{16}$. Na pierwszym z nich widnieje wpis: „Od autora”. Nie zachowały się natomiast w księgozbiorze pozostałe teksty ks. Salamuchy, podobnie zresztą jak publikacje odnotowane w inwentarzu w roku 1932 i 1937: Kilka uwag o nowoczesnej etyce seksualnej ks. Władysława Wichra (1888-1969), wykładowcy teologii moralnej oraz Religia a autorytet (Lwów 1936) autorstwa ks. Władysława Grzelaka (1886-1944), profesora teologii fundamentalnej.

W latach 1922-1939 w Krakowie przebywał francuski historyk Kościoła, liturgista ks. Pierre David (1882-1955). Na Wydziale Teologicznym UJ oprócz liturgiki wykładał języki koptyjski i francuski. W kręgu zainteresowań naukowych ks. Davida znalazła się również historia Polski, co potwierdza liczba prac poświęconych tej tematyce ${ }^{17}$, w tym przekazane do biblioteki w 1934 r., w formie odbitki z „Collectanea Theologica”, Przepisy archidiakona krakowskiego Bartomieja Gądkowskiego (1546-1548) (Kraków 1933).

Pod koniec 1937 r. w księdze inwentarzowej odnotowano dwa dary autorskie ks. Franciszka Śmidody CM (1902-1944), historyka Kościoła i wicerektora Śląskiego Seminarium Duchownego od 1935 r. do początku okupacji w 1939 r. Były to Ks. Gabriel Piotr Baudouin i Jego Dzieto w latach 1732-1768 (Warszawa 1938) opatrzony dedykacją: „Bibliotece Śląskiego Seminarium Duchownego składa swoją pracę X. Fr. Śmidoda 10/XI/1937” oraz O „Historii Kościoła” ks. Umińskiego (Kraków 1937).

Spośród duchownych krakowskich najwięcej swoich publikacji ofiarował ks. Mateusz Jeż (1862-1949). Wprawdzie nie wchodził w skład grona profesorskiego uczelni, jednak był znanym pedagogiem i propagatorem kultu eucharystycznego $^{18}$. Na przestrzeni lat 1930-1938 zbiory biblioteczne wzbogaciły się o: Chwała Ci Maryjo! Pienia ku czci Niepokalanej Bogarodzicy Dziewicy (Kraków 1930), Przed Najświętszym Sakramentem (Kraków 1931), W 1900 rocznicę ustanowienia Najśw. Sakramentu (Kraków 1934), Ku chwale Bogarodzicy Niepokalanie

bliotece Ślaskiego Seminarium Duchownego w Krakowie, „Studia i Materiały z Dziejów Śląska”, 26 (2005) s. 222-229.

${ }^{16}$ Ztota księga, s. 519-526.

${ }_{17}$ Słownik polskich teologów katolickich 1918-1981, t. 5, red. L. Grzebień, Warszawa 1983, s. 279-281.

${ }^{18}$ Tamże, s. 599-603. 
Poczętej (Kraków 1935), Bogu na chwatę! (Kraków 1938). Przekazywanych książek ks. Jeż nie podpisywał, ale na Ku chwale ... zachowała się pieczątka: „Pamiątka 50 letniego Jubileuszu Kapłańskiego 1885-1935 ks. Mateusza Jeża”.

Nie mniejszą troskę o powiększanie zbiorów nowej biblioteki wykazywali kapłani rodzimej katowickiej diecezji, przekazując dary autorskie. Do grona darczyńców należeli przede członkowie śląskich instytucji wspierających bibliotekę. Już w 1926 r. powołana została komisja diecezjalna celem propagowania i uzupełniania biblioteki śląskiego seminarium duchownego ${ }^{19}$. Jej przewodniczący, przyszły biskup sufragan katowicki, ks. Teofil Bromboszcz (1886-1937) w 1928 r. podarował Die Einheit des Johannesevangelismus (Katowice 1927). Była to praca doktorska obroniona w 1918 r. na Wydziale Teologicznym Uniwersytetu we Wrocławiu, a pisana podczas pełnienia funkcji kapelana na frontach pierwszej wojny światowej ${ }^{20}$.

Dla tworzącej się biblioteki duże znaczenie, oprócz komisji diecezjalnej, miało także Towarzystwo Naukowe Kapłanów Śląskich oraz Towarzystwo Przyjaciół Nauk na Śląsku. Wszystkie te instytucje łączyła osoba jednego z najwybitniejszych kapłanów ziemi śląskiej ks. Emila Szramka (1887-1942). Był on autorem wielu publikacji, jednak zasadniczą część jego dorobku stanowiły prace o charakterze biograficznym ${ }^{21}$, z których część drukowana była m.in. na łamach „Gościa Niedzielnego”, „Roczników Towarzystwa Przyjaciół Nauk na Śląsku” i „Wiadomości Diecezjalnych". Do najważniejszych biogramów należały szkice: Ks. Jan Kapica. Życiorys a zarazem fragment z historji Górnego Śląska (Katowice 1931) oraz Ks. Aleksander Skowroński. Obrazki życia i pracy na tle problematyki Kresów Zachodnich (Katowice 1936), które są „,kluczem do zrozumienia metodologii, podejścia biografa w kreowaniu wizerunku osobowościowego interesującej go osoby, a równocześnie pozwalają poznać stosunek samego autora do poruszanych kwestii"22, podarowane w 1931 i 1936 r. bibliotece.

Biografistyka była również pasją współpracującego z Towarzystwem Przyjaciół Nauk na Śląsku ks. Jana Kudery (1872-1943), autora licznych prac do dziejów Górnego Śląska. Przekazana w 1938 r. rozprawa Walenty Roździeński sławny mistrz i autor książki O hutnictwie Ślaska w XVII wieku (Mysłowice 1938) zawiera nie znane dotąd fakty z biografii słynnego kuźnika ${ }^{23}$. Nie mniejszą wartość dla dziejopisarstwa śląskiego posiada ofiarowana w 1935 r. Historja parafji mystowickiej (Mysłowice 1934) tak oceniona przez Ludwika Musioła: „Za to z uwagi na

${ }^{19}$ Wiadomości diecezjalne, „Gość Niedzielny”, 10 (1926) s. 4.

${ }^{20}$ Więcej o dziele bpa Bromboszcza zob. J. Włosek, Życie i działalność księdza biskupa Teofila Bromboszcza w latach 1886-1937, Katowice 1987, s. 53-56 [mps], Biblioteka Teologiczna; S. Pisarek, Biskup Teofil Bromboszcz (1886-1937) jako biblista, „Śląskie Studia Historyczno-Teologiczne”, 27/28 (1994-95) s. 221-228; M. Moj, Biskup Teofil Bromboszcz jako biblista, „Śląskie Studia Historyczno-Teologiczne", 43 (2010) z. 1, s. 151-154.

${ }^{21} \mathrm{~K}$. Tałuć, Biogram jako forma upamiętnienia zastużonych Górnoślązaków w dorobku naukowym ks. Emila Szramka, „Kwartalnik Opolski”, 49 (2003) z. 1, s. 63-71.

${ }^{22}$ Taż, Emil Szramek, Jan Kudera, Konstanty Prus - pierwsze pokolenie badaczy ślaskiego regionalizmu literackiego, Katowice 2002, s. 26.

${ }^{23}$ Tamże, s. 92. 
przeznaczenie pracy podnieść należy zaletę książki: dzieło pisał szczery i gorący patriota polski, nie znający w tej dziedzinie kompromisu. Z podniesienia godną otwartością darzy ostrą krytyką zabiegi germanizatorskie, wobec których zaznaczały się od połowy XIX w. ustępstwa również wśród duchowieństwa miejscowego" 24 .

Do grona darczyńców zalicza się też ks. Waleriana Jasińskiego (1904-1981), ojca duchownego w Śląskim Seminarium Duchownym w latach 1933-1935, późniejszego katechetę Prywatnego Męskiego Gimnazjum im. św. Jacka w Katowicach oraz kapłana dla szkół w Orchard Lake, badacza duszpasterstwa polonijne$\mathrm{go}^{25}$. W latach 1936-1937 zasób biblioteczny powiększył się o jego najnowsze publikacje: Na przełomie myśli wychowawczej. Pedagogika wspótczesna a pedagogika chrześcijańska (Poznań 1936) i referat wygłoszony w czasie II Katolickiego Studium w Wilnie w 1936 r. - Światłocienie współczesnej pedagogiki (Poznań 1937). Obydwie prace pochodzą z okresu, w którym w twórczości ks. Jasińskiego dominowała tematyka katechetyczno-pedagogiczna. W pierwszej, autor przedstawił kryzys jaki przeżywała pedagogika w latach 1900-1933, w drugiej natomiast prądy filozoficzne i ich wpływ na działania pedagogiczno-katechetyczne rodziny i Kościoła ${ }^{26}$.

Ks. Rudolf Tomanek (1879-1941), kaznodzieja, publicysta, prezes Dziedzictwa bł. Jana Sarkandra w Cieszynie, więzień obozu koncentracyjnego w Dachau $^{27}$, przekazał w latach 1928-1929 dwie publikacje. Pierwszą z nich była książka Protestantyzm na Ślasku Cieszyńskim w świetle prawdy, czyli ,, Wiązanka z prasy protestanckiej na Sląsku” (Przedruk z „Gwiazdki Cieszyńskiej”) (Cieszyn 1928), którą wydał pod pseudonimem Paweł Prawdzic ${ }^{28}$; druga z kolei stanowiła jego pionierskie osiągnięcie - przekład - Lekcje i Ewangelje (perykopy) na każdy dzień roku kościelnego (Cieszyn 1930).

W 1935 r. ks. Józef Buryan (1883-1950), proboszcz parafii św. Michała Archanioła w Goleszowie ${ }^{29}$, podarował Ską pochodzi twoje imię i nazwisko i nazwa miejscowości rodzinnej? (Zwięzly zarys imiennictwa polskiego) (Warszawa 1933). $\mathrm{Na}$ odwrocie karty tytułowej zachowała się dedykacja: „Dla biblioteki Seminarjum Śląskiego ofiaruje autor ks. J. Buryan. 15.VII.1935”.

Pod rokiem 1938 odnotowano w księdze inwentarzowej kolejne znakomite prace śląskich duchownych. Należą do nich przede wszystkim największe dzieła

${ }^{24}$ L. Musioł, Jan Kudera: Historia parafii mystowickiej [rec.], „Roczniki Towarzystwa Przyjaciół Nauk na Śląsku", 5 (1936) s. 366-368.

${ }^{25}$ Zob. S. Cichy, Ks. pratat dr Walery Jasiński (1904-1981). Szkic biograficzny i bibliografia za lata 1933-1939, „Śląskie Studia Historyczno-Teologiczne”, $27 / 28$ (1994-95) s. 229-233.

${ }^{26}$ N. Osmańczyk, Ks. Walerian Jasiński, duszpasterz i działacz społeczno-narodowy. (Materiaby do biografii), ,Śląskie Studia Historyczno-Teologiczne”, 17 (1984) s. 219.

${ }^{27}$ Zob. J. Golec, S. Bojda, Stownik biograficzny Ziemi Cieszyńskiej. T. 1, Cieszyn 1993, s. 251252.

${ }^{28}$ Elektroniczny Słownik Biograficzny Śląska Cieszyńskiego. Tryb dostępu: http://slownik.kccieszyn.pl/index.php/online,591. [data dostępu: 29. 10. 2013 r.]

${ }^{29}$ Zob. Stownik biograficzny duchowieństwa (archi)diecezji katowickiej 1922-2008, red. J. Myszor, Katowice 2009, s. 46. 
poświęcone historii Śląska pióra proboszcza parafii w Radzionkowie ks. Józefa Knosały (1878-1951): Bielszowice, Kończyce, Pawłów. Historyczny zarys (Katowice 1928), Geschichte der Stadt Hindenburg O/S Zabrze aus Anlass der Stadtwerdung in Einzelbildern dargestellt (Katowice 1929) oraz monografia dekanatu bytomskiego Das Dekanat Beuthen O/S in seinem schlesischen Teil (Katowice 1935), która oceniona została przez ks. E. Szramka za „żywe opisy czasów i ludzi, które w wielu miejscach dają dobrą historyczną syntezę nie tylko terenu, ale i epoki, czy to będzie wiek trzynasty z licznymi fundacjami kościelnymi, czy czasy późniejsze z t. zw. reformacją i kontrreformacją?" ${ }^{30}$.

Ponadto zbiory biblioteczne wzbogaciły się w tym czasie o najnowsze rozprawy doktorskie przyszłych biskupów. Pierwszą z nich była praca Zagadnienie cierpienia u św. Augustyna (Chorzów 1938) autorstwa ks. Pawła Latuska (1910-1973), wikarego parafii św. Barbary w Chorzowie, podpisana: „Dla Biblioteki Śląskiego Seminarium Duchownego ofiaruje autor". Druga natomiast, to rozprawa zatytułowana Le Concordat de Pologne de 1925 (Paris 1938), która była uwieńczeniem studiów z prawa kanonicznego ks. Herberta Bednorza (1908-1989). Książka ta stanowi trwały wkład w naukę o konkordatach i o stosunkach między Kościołem a państwem, omawia nie tylko konkordat z 1925 r., ale podaje również historyczny przegląd wcześniejszych porozumień zawieranych przez Watykan w odniesieniu do ziem polskich ${ }^{31}$.

O księgozbiorze biblioteki nie zapominał ówczesny biskup katowicki Stanisław Adamski (1875-1967), ofiarując w lutym 1939 r. swoje dzieło Szkoła wedle nauki Kościoła i uchwat Synodu (Katowice 1939). Był to ostatni dar autorski wpisany do inwentarza biblioteki w omawianym okresie.

Wśród darczyńców dla Biblioteki Śląskiego Seminarium Duchownego znaleźli się również duchowni pochodzący z innych diecezji. W 1929 r. biskup kamieniecki, arcybiskup tytularny egejski, liturgista, Piotr Mańkowski (1866-1933) ofiarował Rozważania na tle Piusowego „Motu Proprio” z 22 listopada 1903 r. (Tarnów 1928). Swoje publikacje przekazał także w tym czasie ks. Nikodem Cieszyński (1886-1942), redaktor „Roczników Katolickich”32, członek Poznańskiego Towarzystwa Przyjaciół Nauk, Związku Zawodowego Literatów Polskich ${ }^{33}$. Były to kazania, przykłady bogatej spuścizny kaznodziejskiej i publicystycznej duchownego ${ }^{34}$ : Lud jako lew się podniesie (Num. 23, 24). Zbiór kazań i mów kościelno-narodowych (Poznań 1921), Miecz Ducha. Zbiór kazań kwadransowych na niedziele całego roku (Poznań 1922), Wszystkiem dla wszystkich statem się (1.

${ }^{30}$ E. Szramek, Ks. dr. phil. Josef Knossalla, Das Dekanat Beuthen O/S. in seinem schlesischen Teil [rec.], „Roczniki Towarzystwa Przyjaciół Nauk na Śląsku”, 6 (1938) s. 421-423.

${ }^{31}$ Zob. R. Buchała, Znaczenie pracy ks. Herberta Bednorza o konkordacie polskim dla nauki o stosunkach między Kościołem a państwem, „Chrześcijanin w Świecie”, 122 (1983) s. 28-33.

${ }^{32} \mathrm{Na}$ temat czasopisma zob. D. Kokociński, Nikodema Cieszyńskiego „Roczniki Katolickie” w latach 1923-1939. Analiza zawartości, Poznań 2009.

${ }^{33}$ Zob. Stownik polskich, s. 230-231.

${ }^{34}$ Więcej o działalności pisarskiej ks. Cieszyńskiego zob. D. Pałka, Idea narodu, państwa i polskości w działalności kaznodziejskiej księdza Nikodema Cieszyńskiego, „Ecclesia. Studia z Dziejów Wielkopolski”, 4 (2009) s. 315-332. 
Kor. X, 22) Zbiór kazań przygodnych (Poznań 1927), Wśród pieśni i kadzidet. Garść impresyj religijnych (Poznań 1928). Natomiast w 1937 r. zasoby biblioteczne powiększyły się o dzieło autorstwa ks. Antoniego Zawistowskiego (18821942), profesora biblistyki w Seminarium Duchownym w Lublinie zatytułowane Boska nauka Jezusa Chrystusa (Lublin 1936) i opatrzone dedykacją: „,Dla Biblioteki Duch. Seminarium Śląskiego w Krakowie al. Mick. 3 Ks. Antoni Zawistowski Lublin 4.12.1937 r.".

Przegląd darów autorskich dla biblioteki zamykają publikacje ofiarowane przez osoby świeckie. Jedyną kobietą, która w przedstawianym czasie przekazała swoje prace była mieszkająca w Krakowie Maria Dynowska (1872-1938), wykładowca literatury polskiej na tajnych kompletach dla inteligencji w latach 19091913, autorka szkiców literackich oraz książek dla dzieci i młodzieży ${ }^{35}$. W $1931 \mathrm{r}$. podarowała rozprawę Filip Nereusz Golański na tle wspótczesnej epoki. Studyum dziejom neoklasycyzmu w Polsce poświęcone (Kraków 1916) oraz Korespondencja. 1859-1876. Józef Ignacy Kraszewski, Leopold Kronenberg (Kraków 1929).

W 1937 r. Jerzy Grudziński ofiarował W obronie prawdy-odparcie zarzutów, sprostowania nieścistości i naświetlenie ,,odpowiedzi” publicystyki protestanckiej w Polsce (Cieszyn 1937). Praca została zauważona przez ówczesne środowisko kościelne i uznana jako zasługująca na uwagę, zwłaszcza parafii mieszanych pod względem wyznaniowym ${ }^{36}$.

W gronie darczyńców biblioteki seminaryjnej znalazł się ponadto węgierski historyk Adorján Divéky (1880-1965), od 1928 r. profesor Uniwersytetu Warszawskiego, a w latach 1935-1939 kierownik Instytutu Węgierskiego w Warszawie $^{37}$. W 1930 r. podarował dwa najnowsze dzieła - O katolicyzmie na Wegrzech (Kraków 1930) oraz Święty Emeryk patron młodzieży węgierskiej i jego stosunek do Polski (Warszawa 1930).

Jak można zauważyć, wśród ofiarowanych prac znaczną liczbę stanowiły artykuły wydawane na łamach czasopism i przekazywane, w dużej mierze przez księży krakowskich, w formie odbitek. Niewielka niejednokrotnie objętość nie umniejsza ich wartości, ponieważ autorzy często podejmowali w nich zagadnienia pionierskie w polskiej myśli teologicznej. Na uwagę zasługują wszystkie rozprawy doktorskie oraz cenne opracowania kapłanów młodego Kościoła katowickiego, zwłaszcza te z zakresu historii regionalnej darowane przez księży E. Szramka, J. Kuderę i J. Knosałę, przedstawicieli śląskiego środowiska historycznego Polski międzywojennej ${ }^{38}$.

Najwięcej darów autorskich odnotowano w pierwszym roku funkcjonowania biblioteki oraz w latach 1937-1938. Kilka egzemplarzy nie zachowało się do dnia dzisiejszego. Te, które pozostały są niewielką częścią przedwojennego księgozbioru. Należy się im jednak szczególne zainteresowanie oraz pamięć ponieważ

${ }^{35}$ Polski Stownik Biograficzny. T 6, Kraków 1948, s. 66.

${ }^{36}$ „Miesięcznik Kościelny. Organ Archidiecezyj Gnieźnieńskiej i Poznańskiej”, 53 (1938) nr 8, s. 317.

${ }^{37}$ Literatura polska. Przewodnik Encyklopedyczny. T. 1: A-M, Warszawa 1984, s. 189.

${ }_{38}$ Zob. M. Dyba, Kształtowanie się polskiego środowiska historycznego na Śląsku w latach 1918-1939, Katowice 1993. 
ofiarowane zostały przez samych autorów, w większości wybitnych przedstawicieli polskiego duchowieństwa. Wielu z nich zginęło w czasie II wojny światowej, dwóch - ks. E. Szramek, ks. A. Zawistowski - zostało włączonych w poczet 108 błogosławionych męczenników. Podkreślić ponadto należy, że autor, przekazując pracę do zbiorów danej książnicy, wskazywał tym samym grono jej przyszłych odbiorców, a dodatkowo opatrując dedykacją stwarzał trwałą i wyjątkową więź $\mathrm{z}$ biblioteką.

\section{ANEKS}

Wybrane dedykacje autorskie dla Biblioteki Śląskiego Seminarium Duchownego.

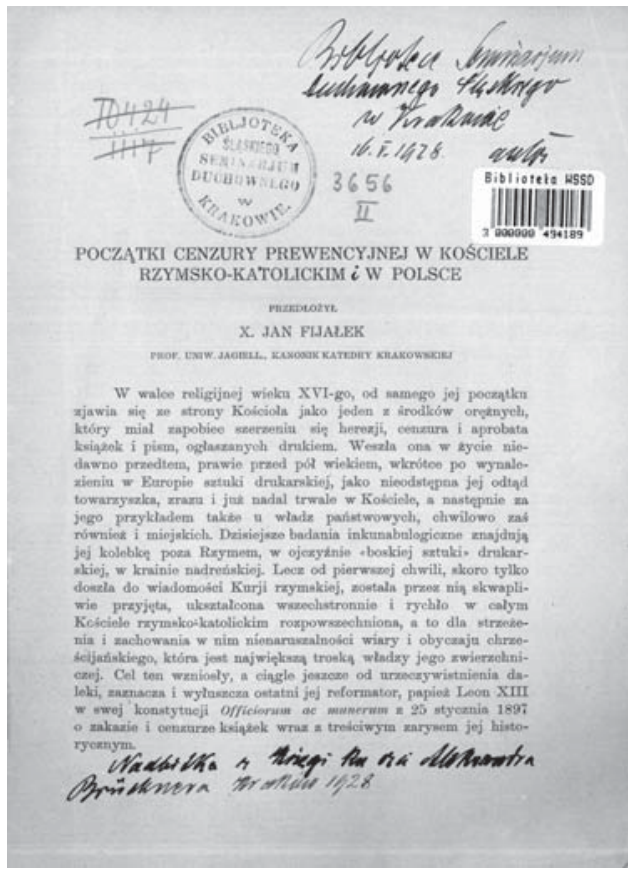

Fot. 1. Dedykacja ks. Jana Fijałka. 


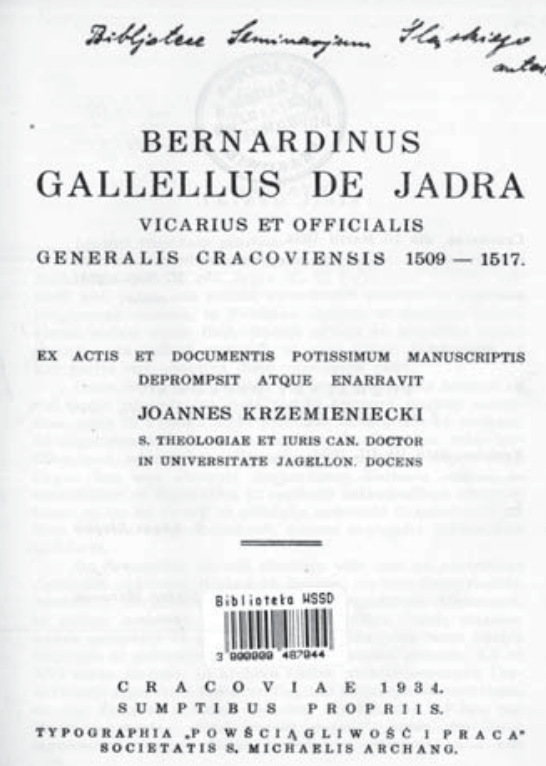

Fot. 2. Dedykacja ks. Jana Krzemienieckiego.

KS. PAWEZ LATUSEK

\section{ZAGADNIENIE CIERPIENIA \\ U ŚW. AUGUSTYNA}

ROZPRAWA DOKTORSKA PRZYJETA PRZEZ RADE, WYDZIALU TEOLOGICZNEGO U. J. NA PODSTAWIE REFERATOW KS. PROF.
DRA M. SIENIATYCKIEGO I KS, PROF, DRA W. WICHRA
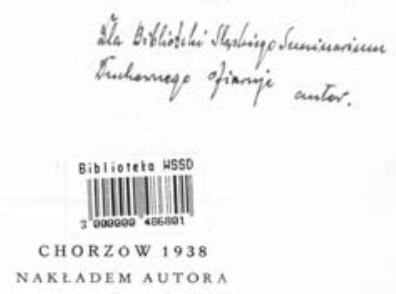

Fot. 3. Dedykacja ks. Pawła Latuska. 


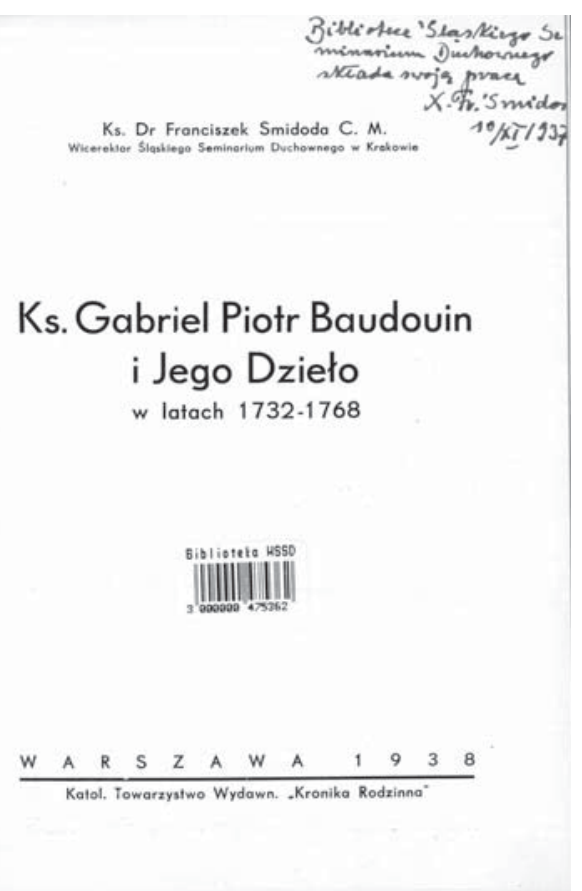

Fot. 4. Dedykacja ks. Franciszka Śmidody CM.

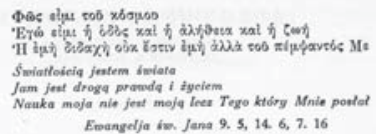

BOSKA NAUKA JEZUSA CHRYSTUSA

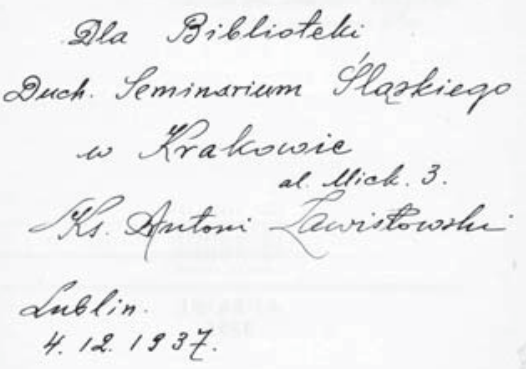

Fot. 5. Dedykacja bł. ks. Antoniego Zawistowskiego. 


\title{
THE BOOKS DONATED BY THE AUTHORS TO \\ THE LIBRARY OF SILESIAN CLERICAL SEMINARY BETWEEN 1928 AND 1939 \\ (A CONTRIBUTION TO RESEARCH WORK ON THE CONTENT OF PREWAR COLECTIONS)
}

\begin{abstract}
Summary
The collections of the Library of Silesian Clerical Seminary, which history dates back to the 1920 s, have not been examined satisfactorily to date. In the interwar period the library built its collections through purchases and generous donations. The article focuses on this part of donations which came from the authors themselves, mainly priests of Kraków archdiocese and Katowice diocese, secular persons in a minor extent. They donated 50 works in total, among them books, dissertations and articles previously published in periodicals. All of them were the latest publications on theology, Church history and related studies and covered a wide spectrum of religious issues. Some books are signed with author's inscription, which greatly increases their value.
\end{abstract}

Translated by Ewa Olszowy 